\title{
Decline and Agricultural Revival of an Old "huerta" at the Gates of Constantine
}

\author{
Salah BOUCHEMAL* \\ RNAMS Laboratory, University of Oum EL Bouaghi, Algeria
}

ISSN: 2637-7659

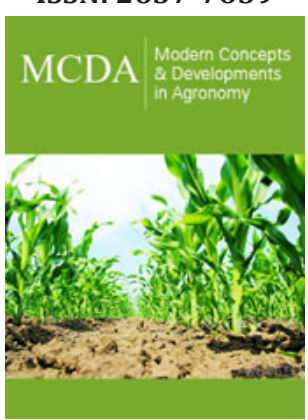

*Corresponding author: Salah BOUCHEMAL, Professor, RNAMS Laboratory, University of Oum EL Bouaghi Algeria

Submission: 啙 August 29, 2020

Published: 眥September 02, 2020

Volume 7 - Issue 2

How to cite this article: Salah BOUCHEMAL. Decline and Agricultural Revival of an Old "huerta" at the Gates of Constantine. Mod Concep Dev Agrono. 7(2). MCDA. 000659. 2020. DOI: 10.31031/MCDA.2020.07.000659

Copyright@ Salah BOUCHEMAL, This article is distributed under the terms of the Creative Commons Attribution 4.0 International License, which permits unrestricted use and redistribution provided that the original author and source are credited.

\section{Opinion}

In Algeria, the rural areas at the gates of the big cities are undergoing a real deconstruction because of the impacts of the urban fact and the interventions on the agrarian structure. The effects are perverse, they endanger the agricultural sector. We become aware of it but we react in small touches. The interest of an analysis of the issue is therefore crucial, since debates on issues relating to food security and sovereignty have long been essential [1].

In this note, we wanted to talk about it by taking the example of the commune of Hamma Bouziane, a space that stands out by its singularity and which, in the past, was sufficient on its own to supply several sectors of Eastern Algeria. It is largely in crisis and the choice for its study must measure its relevance.

The commune of Hamma Bouziane or the Hamma is an old "huerta", it was once the market garden of Constantine and its orchard, a function that has been altered since the decision was taken to transfer the urbanization of the metropolis to its neighboring area. As a mainland "huerta", it has many advantages, both physiographically and economically, due to its proximity to Constantine, which is a very important center of consumption. Exceptional artesian water resources have always favored a rich agriculture, a factor that appears to be a privilege, even compared to the coastal plains.

The agricultural richness of the Hamma, very early attracted the covetousness of the city dwellers. During the period of the Turkish Regency, a large part of the land was held by the wealthy of Constantine [2]. During the French colonial episode, this hold was reinforced by the ownership of the French settlers of Constantine. This resulted in a stranglehold on more than half of the agricultural area, with the rest of the land going to a plethora of small farmers living in the Hamma. The retreat of this hold took place after the establishment, at the time of Independence in 1962, of agricultural self-management, which appeared to be the only possible form of exploitation of vacant colonial farms, and when the texts on the Agrarian Revolution were promulgated in 1971, an operation that allowed the creation of a cooperative sector, the limitation of large property, the nationalization of land held by absentees and a redistribution of land.

Later, other measures were taken, and two major reforms were undertaken. The first, called "Restructuring of the Public Sector," consisted of regrouping the lands of the Agrarian Revolution cooperatives and those of self-management to form "economically viable and humanly manageable" farms. But the expected results were not convincing, this restructuring was simply reduced to a new agro-territorial network and renewed the agrarian dualism produced at Independence. Instituted in 1987, the second reform, known as the "Reorganization of Agriculture", has a very important scope, because it breaks with the socializing agrarian policies. It confirms the failure of technostructures and announces the privatization of the 
public domain [3]. For it was very quickly followed by a land orientation law, by which the ordinance proclaiming the agrarian revolution was repealed. It rehabilitated nationalized property. Moreover, it freed up transactions on agricultural land, thus consolidating the land stranglehold of the cities on the countryside, a stranglehold that was already well pronounced in the Hamma. From the 1970 onwards, in fact, the public authorities allocated agricultural land to urbanization to allow the city of Constantine to expand. It had no more land to urbanize, because of the constraints of its relief [4].

The Law on the Reorganization of Agriculture gave producers a right of perpetual enjoyment of all public land, which was divided into EAC (Collective Farming) and EAI (Individual Farming), with a management method in which the State's disengagement is almost total. This liberal choice in the management of these farms also failed to improve the incomes, still in decline, of producers who were not prepared to practice the market economy. Very quickly, conflicts arose and led to the break-up of the EAC for an individual sharing of plots of land, because-and it remains true-the law did not provide for the obligation of common exploitation, nor the principle of recognition of the shares of each farmer, especially since a law converted the right of perpetual enjoyment into a 40 years concession right.

In the Hamma, this fragmentation affected the majority of the EAC. In several cases, the beneficiaries of land concessions adjacent to the urban perimeter have expressed their impatience to see the promulgation of texts authorizing the integration of their plots in urban plans. they will then be sold at the price of land to be urbanized and will allow rapid enrichment. This vision of agricultural land as a land reserve for urbanization is also that of several farmers whose land is located on the edge of the urban perimeter, and under other legal statuses. Their strategy is simple, they will leave their lands fallow so that they are easily urbanized, compared to those developed for agriculture [5]. Some of them engage in other practices, such as the diversion of land use through illegal constructions or the proliferation of non-agricultural activities.

The practices that contribute to land-use change are multiple and take different forms. They have consequences on the organization of the agrarian landscape and hinder the development of an agriculture that has been in decline for a long time, due to the withdrawal of arable land by urbanization, to solve the housing crisis and to install the infrastructure and equipment necessary for a growing population of nearly 100.000 inhabitants for the whole of the Hamma. This population, which barely exceeded 14.000 people in 1966, began to grow in 1970, when a cement factory and a flour mill were created in the heart of the plain, both generating numerous jobs. Housing was then built around these two production units and later developed an urbanization that, by spreading out like an oil stain, transgressed the proper functioning of agrarian life.

However, despite the pressure on land use, the Hamma's agriculture, although weakened, remains an important economic sector, as it continues to support several hundred families. Land use is at the origin of a territoriality where the stakes and their consequences are multiple: speculation on agricultural land, water conflicts, environmental damage, decline in agricultural activity but also agricultural renewal when conditions are favoesrable and allow the creation of innovative projects. We will be there in a dynamic that will necessarily meet the objectives of the agricultural and rural renewal policy that the public authorities have launched to "sustainably strengthen food security" in the country. At the Hamma, the performance of certain producers, who have demonstrated innovation and know-how in this field, is proof of this.

This note is the starting point for more comprehensive work. It will explain in great detail the decline of this ancient "huerta" and the induced effects, the strategies of the actors facing the vulnerability of the land and the factors that have stimulated an agricultural revival bringing hope for a sustainable territorial development.

\section{References}

1. Semmoud B, Laadhem A (2015) L’agriculture périurbaine face aux vulnérabilités foncières en Algérie. Territoires en mouvement : revue de géographie et d'aménagement. pp. 25-26.

2. El Hadeuf L (1982) Hamma Bouziane: mutations d'une commune rurale péri-urbaine. Revue du CIEM, Université de Poitiers, France, pp. 193227.

3. Bouchemal S (1997) Mutations agraires en Algérie. L Harmattan, Paris, France, pp. 1-272.

4. Boudjenioua A, Fleury A, Tacherift A (2006) Le statut agricole périurbain à Sétif (Algérie) : réserve foncière ou projet urbain? Cahiers Agricultures 15(2): 221-226.

5. Soulard ChT, Valette E, Perrin C, Abrantes P, Theodosia A (2018) Periurban agro-ecosystems in the Mediterranean: diversity, dynamics, and drivers. Reg Environ Change 18: 651-662. 